\title{
PENGARUH MEDIA VIDEO TERHADAP KESIAPSIAGAAN SISWA DALAM MENGHADAPI BENCANA GEMPABUMI DI SMA NEGERI 1 GANTIWARNO, KLATEN
}

\author{
Fajar Wulandari \\ ' Fakultas Ilmu Keguruan dan Ilmu Pendidika, Universitas Muhammadiyah Surakarta, Indonesia \\ E-mail: fajarwulandari3@gmai..com
}

\begin{abstract}
Abstrak. Penelitian ini bertujuan mengetahui penggunaan media video terhadap kesiapsiagaan siswa menghadapi bencana gempabumi di SMA Negeri 1 Gantiwarno. Penelitian ini dilakukan dengan pendekatan deskriptif kuantitatif sebelumnya dilakukan uji prasyarat analisis menggunakan metode Kolmogorov Smirnov untuk uji normalitas dan metode Levene Test untuk uji homogenitas, dengan populasi siswa SMA Negeri 1 Gantiwarno sebagai kelompok siswa yang rentan terhadap bencana gempabumi di sekolah. Sampel yang diambil yaitu 50 siswa dari kelas X, XI IPA 1, XI IPA 2, XI IPS 1, XII IPA 1, XII IPA 2, XII IPS 1, XII IPS 2. Hasil penelitian menyimpulkan 1) Hasil data diketahui dapat meningkatkan kesiapsiagaan siswa SMA Negeri 1 Gantiwarno menghadapi bencana gempabumi. Nilai indeks gabungan kesiapsiagaan siswa sebelum diberikan media video adalah 63,83 termasuk kategori hampir siap dengan presentase sangat siap (10\%), siap (32\%), hampir siap (44\%), kurang siap (12\%) belum siap (2\%), sedangkan tingkat kesiapsiagaan siswa SMA Negeri 1 Gantiwarno menghadapi bencana gempabumi sesudah diberikan media video dengan perolehan nilai 78,79 termasuk kategori siap dengan presentase sangat siap (46\%), siap (36\%), hampir siap (16\%), kurang siap (2\%) belum siap (0\%). 2) Penggunaan media video dapat meningkatkan kesiapsiagaan siswa menghadapi bencana gempabumi.
\end{abstract}

Keywords: Media Video, Kesiapsiagaan, Bencana, Gempabumi

\section{Pendahuluan}

Gempabumi yang menimbulkan getaran kuat terjadi di DI Yogyakarta dan daerah Jawa Tengah pada tanggal 27 Mei 2006 merupakan salah satu gempabumi tektonik akibat pergeseran lempeng bumi yang aktif, dengan berkekuatan 5,9 SRberpusat di kedalaman $17 \mathrm{~km}$ di bawah permukaan kawasan Pantai Parangteritis, Kabupaten Bantul.

Kabupaten Klaten yang ikut pula terkena getaran dari gempabumi yang terjadi yang berlangsung selama kurang lebih 52 detik, setelah gempa bumi tersebut terjadi menimbulkan dampak kerusakan yang parah data dari informasi dibi BNBP (Badan Nasional Penanggulangan Bencana) di Kabupaten Klaten Provinsi Jawa Tengah, jumlah korban meninggal 1045 orang, luka-luka 18127 orang.

Gempabumi susulan terjadi di Kecamatan Gantiwarno Kabupaten Klaten merupakan gempa bumi yang terjadi pukul 11.44 berkekuatan 3,8 Skala Richter gempa bumi susulan ini berpusat di Kecamatan Gantiwarno setelah gempa tektonik pertama terjadi pada 27 mei 2006, karena terjadi pergeseran lempeng bumi di daerah Gantiwarno yang sedang terjadi penyeimbangan akibat pergeseran lapisan bumi yang menimbulkan gempabumi dari laut selatan ke arah Bantul dan Klaten. Kerusakan yang terjadi di Kecamatan Gantiwarno Kabupaten Klaten, dari 16 Desa hampir seluruhnya mengalami kerusakan total. Desa Jabung mengalami kerusakan total sebanyak 948 rumah dan korban jiwa sebanyak 2876 sedangkan Desa Getasan mengalami rusak total 82 rumah dan 1651 korban jiwa (sumber data: Bappeda).

Penelitian yang dilakukan di SMA Negeri 1 Gantiwarno, karena SMA Negeri 1 gantiwarno terkena bencana gempabumi tektonik sehingga proses belajar mengajar di kelas akibat terjadinya gempabumi. Bangunan sekolah pun tak luput dari kerusakan dan menimbulkan kerugian bagi pihak sekolah. Gempabumi tidak dapat dihindari namun, kita dapat memperkecil resiko dengan meningkatkan pertahanan dan pengetahuan tentang kesiapsiagaan menghadapi bencana gempabumi, siswa akan lebih mudah menerima pembelajaran melalui sarana seperti media.

Kesiapsiagaan adalah suatu tindakan atau perilaku yang tepat dan efektif pada saat dan setelah terjadi bencana yang harus dimiliki oleh setiap individu, sehingga dapat menjaga diri atau antisipasi terhadap bencana.

Media pembelajaran dapat mengatasi keterbatasan pengalaman yang dimiliki oleh siswa, sehingga melalui media video yang dijelaskan oleh guru kepada siswa dapat mempermudah siswa dalam mengerti pembelajaran secara internal maupun eksternal.

Pernyataan di atas yang melatarbelakangi penulis untuk melakukan peneitian di SMA Negeri 1 Gantiwarno, Kabupaten Klaten dengan judul Pengaruh Media Video 
terhadap Kesiapsiagaan dalam menghadapi Bencana Gempabumi Di SMA Negeri Gantiwarno.

\section{METODE}

Penelitian ini menggunakan metode eksperiment, untuk mencari pengaruh perlakuan Populasi pada penelitian ini adalah seluruh siswa SMA Negeri 1 Gantiwarno yaitu sejumlah 100 siswa, dengan pengambilan sampel sebanyak 50 siswa dengan metode sampel random sampling. Variable dalam penelitian ini adalah variable kontrol karena penelitian akan membandingkan tingkat kesiapsiagaan siswa dalam menghadapi bencana gempabumi sebelum dan setelah diberikan perlakuan media video pembelajaran gempabumi.

\section{ANALISIS DATA}

Analisis data pada penelitian ini digunakan untuk mengetahui tingkat kesiapsiagaan dalam menghadapi bencana gempabumi di SMA Negeri 1 Gantiwarno, sebelum dan setelah diberikan media video kemudian hasil dari analisis data dijabarkan melalui analisa deskriptif kuantitatifdengan indeks kesiapsiagaan siswa dalam menghadapi bencana gempabumi, dan dihitung berdasarkan rumus, sebagai berikut:

$$
\text { Indeks } \frac{\text { total skor rill parameter }}{\text { skor maksimum parameter }} \times 100
$$

Rumus Menghitung Kesiapsiagaan dalam Menghadapi Bencana

Sehingga dari rumus di atas akan diketahui kesiapsiagaan siswa dalam menghadapi bencana gempabumi di SMA Negeri 1 Gantiwarno

\section{HASIL DAN PEMBAHASAN}

A. Tingkat Keiapsiagaan Siswa dalam Menghadapi Bencana Gempabumi

Penelitian ini dilakukan untuk mengetahui pengaruh penggunaan media video terhadap kesiapsiagaan siswa SMA Negeri 1 Gantiwarno dalam menghadapi bencana gempabumi dilihat dari angket yang telas diisi oleh responden sebelum dan sesudah diberikan media video. Kesiapsiagaan siswa sebelum diberikan media video adalah 63,83 termasuk kategori hampirsiap dengan presentase sangat siap (10\%), siap (32\%), hampir siap (44\%), kurang siap (12\%) dan belum siap (2\%), sedangkan tingkat kesiapsiagaan siswa SMA Negeri 1 Gantiwarno dalam menghadapi bencana gempa bumi sesudah diberikan media video dengan perolehan nilai 78,79 termasuk kategori siap dengan presentase sangat siap (46\%), siap $(36 \%)$, hampir siap $(16 \%)$, kurang siap $(2 \%)$ dan belum siap $(0 \%)$. Setelah dilakukan analisis data dapat diketahui pengaruh penggunaan media video dengan penjelasan perhitungan paired samplet T-Test, dibawah ini:
Tabel1. Analisis Data Hipotesis

Paired Samples Test

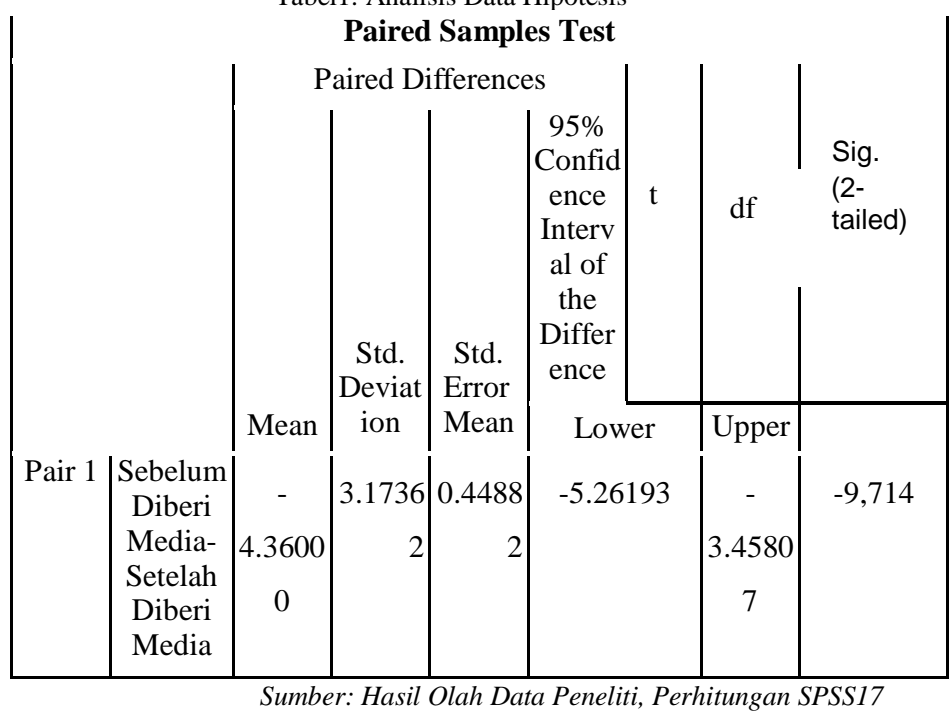

Perhitungan uji beda paired samplet T-Tes menunjukkan hasil nilai $t_{\text {hitung }}-9,714$ dengan sig 0,000 atau $<0,05$ maka $h_{0}$ ditolak, artinya media video berpengaruh terhadap kesiapsiagaan siswa dalam menghadapi gempa bumi di SMA Negeri 1 Gantiwarno. Hasil penelitian di atas menunjukkan bahwa kegiatan memberikan media video dapat menambah kesiapsiagaan siswa dalam menghadapi bencana gempa bumi

\section{KESIMPULAN}

Kesimpulan:

1. Ditinjau dari tingkat kesiapsiagaan siswa SMA Negeri 1 Gantiwarno dalam menghadapi bencana gempa bumi sebelum diberikan media pembelajaran dengan sarana video termasuk kategori hampir siap, dan sesudah diberikan media pembelajaran dengan sarana video termasuk kategori siap.

2. Pengaruh penggunaan media video terhadap tingkat kesiapsiagaaan siswa SMA Negeri 1 Gantiwarno dalam menghadapi bencana gempa bumidiperoleh hasil nilai $t_{\text {hitung }}$ sebesar -9,714dengan sig 0,000.

\section{REFERENCES}

Arikunto Suharsimi. 2010. Prosedur Penelitian Suatu Pendekatan Praktik. Jakarta, Penerbit RINEKA CIPTA.

Bintarto R. 1979. Metode Analisa Geografi. Jakarta, Penerbit LP3ES.

Badan Pusat Statistik. 2010. Gantiwarno Dalam Angka.Klaten.

Cristanto Joko. 2011. Gempa Bumi Kerusakan Lingkungan kebijakan dan Strategi

Pengelolaan.Yogyakarta, Penerbit Liberty Yogyakarta.

Katili. 1963. Geologi. Pencetak KILATMADJU. Bandung. Indonesia.

Marsudi Saring. 2008. Perkembangan Peserta Didik.Surakarta, BP-FKIP UMS.

Noor Djauhari. 2006. Geologi Lingkungan. Jakarta, Penerbit Graha Ilmu. 
Nurjanah, dkk. 2012. Manajemen Bencana. Bandung, Penerbit Alfabeta.

Pribadi, S. Krishna. 2008. Buku Pegangan Guru : Pendidikan Siaga Bencana. Bandung: Pusat Mitigasi Bencana - Institut Teknologi Bandung.

Riduwan. 2012. Metode\&Teknik Menyusun Proposal Penelitian. Bandung, Penerbit Alfabeta.

Sadiman Arief, dkk. 2002. Media Pendidikan Penertian, Pengembangan dan Pemanfaatannya. Jakarta, Penerbit RajaGrafindo Persada.

Sanaky, AH. Hujair. 2013. Media Pembelajaran InteraktifInovatif. Yogyakarta, Penerbit KAUKABATA DIPANTARA.

Sopaheluwakan Jan, Deny Hidayati, Haryadi Permana, Krishna Pribadi, Febrin, Ismail, Koen Meyers, Widayatun, Titik Handayani, Del Afriadi Bustami, Daliyo, Fitranita, Laila Nagib, Ngadi, Yugo Kumoro, Irina Rafliana, Teti Argo. 2006. Kajian Kesiapsiagaan Masyarakat dalam Mengantisipasi BencanaGempa Bumi dan Tsunami. Lipi Unesco/Isdr.

Suardi Moh. 2012. Pengantar Pendidikan Teori dan Aplikasi. Jakarta, PT.Indeks.

Sugiyono. 2013. Metode Penelitian Kuantitatif, Kualitatif dan $R \& D$. Bandung, $\quad$ Penerbit Alfabeta Bandung.

Undang-Undang Republik Indonesia Nomor 24 Tahun 2007 Tentang Penanggulangan Bencana.

Widiyanto Joko. 2010. SPSS For Windows Untuk Analisis Data Statistik dan Penelitian. Surakarta, Laboraturium FKIP UMS.

"Pusat Gempa di Gantiwarno". SUARA MERDEKA, Jumat, 09 Juni 2006. (Diakses pada tanggal 5 November 2013, pukul: 10:52.)

"Video Kesiapsiagaan Dalam Menghadapi Bencana Gempa Bumi Bagian 1" LIPI

2008 (http://www.youtube.com/watch?v=tMZNDv1ykuc) diakses pada tanggal Minggu 11 Juni 2013, pukul 20:13.

"Video Kesiapsiagaan Dalam Menghadapi Bencana Gempa Bumi Bagian 2" LIPI

2008 (http://www.youtube.com/watch?v=Z5oQyZp2 X0) diakses pada tanggal Minggu 11 Juni 2013, pukul 20:30. 